2005

\title{
3,4-Methylenedioxymethamphetamine Activates Nuclear Factor- $\kappa B$, Increases Intracellular Calcium, and Modulates Gene Transcription in Rat Heart Cells
}

\section{David A. Tiangco}

Old Dominion University, dtian001@gsa.odu.edu

Frank A. Lattanzio Jr.

Christopher J. Osgood

Old Dominion University, cosgood@odu.edu

Stephen J. Beebe

Julie A. Kerry

See next page for additional authors

Follow this and additional works at: https://digitalcommons.odu.edu/biology_fac_pubs

Part of the Biology Commons, and the Cellular and Molecular Physiology Commons

\section{Repository Citation}

Tiangco, David A.; Lattanzio, Frank A. Jr.; Osgood, Christopher J.; Beebe, Stephen J.; Kerry, Julie A.; and Hargrave, Barbara Y., "3,4-Methylenedioxymethamphetamine Activates Nuclear Factor- $\kappa B$, Increases Intracellular Calcium, and Modulates Gene Transcription in Rat Heart Cells" (2005). Biological Sciences Faculty Publications. 381.

https://digitalcommons.odu.edu/biology_fac_pubs/381

\section{Original Publication Citation}

Tiangco, D. A., Lattanzio Jr, F. A., Osgood, C. J., Beebe, S. J., Kerry, J. A., \& Hargrave, B. Y. (2005).

3,4-Methylenedioxymethamphetamine activates nuclear factor- $\mathrm{kB}$; , increases intracellular calcium, and modulates gene transcription in rat heart cells. Cardiovascular Toxicology, 5(3), 301-310. doi:10.1385/CT:5:3:301 
Authors

David A. Tiangco, Frank A. Lattanzio Jr., Christopher J. Osgood, Stephen J. Beebe, Julie A. Kerry, and Barbara Y. Hargrave 


\section{3,4-Methylenedioxymethamphetamine Activates Nuclear Factor- $\kappa B$, Increases Intracellular Calcium, and Modulates Gene Transcription in Rat Heart Cells}

\section{David A. Tiangco, ${ }^{1}$ Frank A. Lattanzio, Jr., ${ }^{2}$ Christopher J. Osgood, ${ }^{1}$ Stephen J. Beebe, ${ }^{3}$ Julie A. Kerry, ${ }^{4}$ and Barbara Y. Hargrave ${ }^{1, *}$}

${ }^{1}$ Department of Biological Sciences, Old Dominion University, Norfolk, VA; ${ }^{2}$ Department of Physiological Sciences, ${ }^{3}$ Center for Pediatric Research; and ${ }^{4}$ Department of Microbiology and Molecular Cell Biology, Eastern Virginia Medical School, Norfolk, VA
*Author to whom all correspondence and reprint requests should be addressed: Barbara Y. Hargrave, PhD, Department of Biological Sciences, Old Dominion University, Hampton Boulevard,

Norfolk, VA 23529.

E-mail: bhargrav@odu.edu

Cardiovascular Toxicology, vol. 5, no. 3, 301-310, 2005

\section{Abstract}

3,4-Methylenedioxymethamphetamine (MDMA) is an illicit psychoactive drug that has gained immense popularity among teenagers and young adults. The cardiovascular toxicological consequences of abusing this compound have not been fully characterized. The present study utilized a transient transfection/dual luciferase genetic reporter assay, fluorescence confocal microscopy, and gene expression macroarray technology to determine nuclear factor- $\kappa \mathrm{B}$ (NF-kB) activity, intracellular calcium balance, mitochondrial depolarization, and gene transcription profiles, respectively, in cultured rat striated cardiac myocytes (H9c2) exposed to MDMA. At concentrations of $1 \times 10^{-3} \mathrm{M}$ and $1 \times 10^{-2} M$, MDMA significantly enhanced NF- $\kappa B$ reporter activity compared with $0 M$ (medium only) control. This response was mitigated by cotransfection with $1 \kappa B$ for $1 \times 10^{-3} \mathrm{M}$ but not $1 \times 10^{-2} \mathrm{M}$ MDMA. MDMA significantly increased intracellular calcium at concentrations of $1 \times 10^{-3} \mathrm{M}$ and $1 \times 10^{-2}$ $M$ and caused mitochondrial depolarization at $1 \times 10^{-2}$ M. MDMA increased the transcription of genes that are considered to be biomarkers in cardiovascular disease and genes that respond to toxic insults. Selected gene activation was verified via temperature-gradient RT-PCR conducted with annealing temperatures ranging from $50^{\circ} \mathrm{C}$ to $65^{\circ} \mathrm{C}$. Collectively, these results suggest that MDMA may be toxic to the heart through its ability to activate the myocardial $\mathrm{NF}-\kappa \mathrm{B}$ response, disrupt cytosolic calcium and mitochondrial homeostasis, and alter gene transcription.

Key Words: MDMA; NF-кB; nuclear factor; H9c2; cardiac myocytes; calcium.

\section{Introduction}

3,4-Methylenedioxymethamphetamine (MDMA) is an illicit psychoactive drug taken for its mood-altering and stimulating effects. This drug shares structural homology with amphetamine and mescaline, which helps explain its hybridized pharmaco- 
logical properties (1). MDMA is a particular favorite among teens and young adults at all-night dance parties called "raves" and often goes by the street name "ecstasy." Although considered safe by many users, studies have shown that MDMA may in fact be detrimental to multiple organ systems including the cardiovascular system (1-3).

In human subjects, MDMA use is associated with abnormal increases in heart rate, mean arterial pressure, and myocardial wall stress (2). In rats, binge pattern intravenous administration of MDMA $(9 \mathrm{mg} / \mathrm{kg})$ can cause profound and progressive bradycardia with accompanying hypotension (3). Autonomic dysregulation is suspected to contribute to the rhythmic and pressor abnormalities seen with MDMA abuse and may involve increased net release of norepinephrine and $\alpha$-adrenergic receptor interaction $(1,4,5)$. In addition, elevated intracellular calcium, as seen with other stimulants such as cocaine, may lead to further complications including myocardial hypertrophy, fibrosis, and apoptosis (6).

The mechanism(s) by which MDMA causes adverse cardiovascular effects remains unclear. One transcription factor that may be activated by MDMA is nuclear factor- $\kappa \mathrm{B}(\mathrm{NF}-\kappa \mathrm{B})$. NF- $\kappa \mathrm{B}$ is a ubiquitous protein transcription factor found in a wide variety of cell types as a heterodimer consisting of p50 and p65 subunits (7-10). Under basal conditions, NF- $\mathrm{B}$ is localized mainly in the cytoplasm, where it is tonically inhibited by reversible binding to an inhibitory (I- $\kappa \mathrm{B}$ ) family of regulatory proteins (11). Activation occurs when I $\kappa$ B becomes phosphorylated and subsequently degraded, allowing for translocation of the heterodimer to the nucleus, where NF- $\kappa \mathrm{B}$ binds to $\kappa \mathrm{B}$-response elements in the promoter/enhancer regions of various genes $(7,12-17)$. This process upregulates the expression of inflammatory cytokines, chemotactic proteins, and cellular adhesion molecules (17). Several known inducers of NF- $\kappa B$ include interleukin $1 \beta$ (IL)- IL-6, IL-8, tumor necrosis factor (TNF)- $\alpha$, lipopolysaccharide, physical trauma, ionizing radiation, and free radicals (18-22).

In the heart, there is evidence that NF- $\kappa \mathrm{B}$ is proinflammatory as well as antiapoptotic. Cultured cardiac myocytes exposed to hydrogen peroxide show an increased activation of NF- $\mathrm{BB}$ (23). Myocardial intercellular adhesion molecule-1 and vascular cell adhesion molecule-1 (VCAM-1) gene expression are effectively reduced in the presence of NF- $\kappa \mathrm{B}$ inhibitors $(24,25)$. These cell surface proteins are important in mediating inflammatory cell recruitment and infiltration by acting as counter-receptors for circulating monocyte and lymphocyte integrins (25). The antiapoptotic nature of NF- $\kappa \mathrm{B}$ has been demonstrated in primary cultures of rat ventricular myocytes. In these cells, TNF- $\alpha$-induced apoptosis is significantly enhanced on NF- $\kappa \mathrm{B}$ inhibition (26).

Currently, there is very little information in the literature concerning the direct effects of MDMA on $\mathrm{NF}-\kappa \mathrm{B}$ regulation and on intracellular calcium homeostasis. One recent study showed that MDMA simultaneously increased reactine oxygen species (ROS) production and depleted reduced glutathione levels in hepatic stellate cells (27). Other investigators have shown that MDMA increases hydroxyl radical formation in the rat brain (28). Theoretically, the oxidative environments imposed by MDMA administration in these studies represent ideal conditions for $\mathrm{NF}-\kappa \mathrm{B}$ activation and subsequent upregulation of the inflammatory response. There is already evidence that links MDMA exposure to increased lymphocyte infiltration and inflammatory damage to the myocardium (myocarditis) (3). However, the degree of NF- $\kappa \mathrm{B}$ involvement with this response remains unknown. From the current available evidence, it is our hypothesis that MDMA may activate NF- $\kappa \mathrm{B}$ in cultured striated heart cells and alter calcium homeostasis. We hypothesize that MDMA can abnormally increase intracellular calcium and modulate the expression of genes important to the myocardial pathological and toxicological response.

\section{Materials and Methods}

\section{Cell Culture and Maintenance}

Cultured rat striated cardiac myocytes (H9c2) from the rat (Rattus norvegicus) were purchased from American Type Culture Collection (ATCC; Bethesda, MD) and cultured in a T- 75 flask at $37^{\circ} \mathrm{C}$ and $5 \%$ atmospheric $\mathrm{CO}_{2}$ (incubator controlled). The culture medium consisted of $15 \mathrm{~mL}$ Dulbecco's Modified Eagle's Medium (ATCC) containing 10\% fetal bovine serum (FBS). With the aid of a hemacytometer, approx 150,000 resuspended cells were plated onto each well of a sterile 12-well culture plate and returned to the incubator for $24 \mathrm{~h}$. 


\section{Measurement of Luciferase Activity}

The transfection procedure was performed over a 4-d period as previously described (29). Briefly, on $\mathrm{d} 1$ of the protocol, approx 150,000 cells were plated onto each well of a 12-well culture plate and returned to the incubator for $24 \mathrm{~h}$. On d 2, the cells were transfected by the FuGENE ${ }^{\mathrm{TM}}$ (Roche, Nutley, NJ) method with $1.0 \mu \mathrm{g}$ of a plasmid containing firefly luciferase DNA coupled to the NF- $\kappa$ B promoter, and $0.1 \mu \mathrm{g}$ of a second plasmid with Renilla luciferase DNA coupled to the constitutively active SV40 promoter (internal control). In a separate set of experiments, 1.0 $\mu \mathrm{g}$ I $\mathrm{B}$ DNA was transfected to determine the drug concentration at which NF- $\kappa \mathrm{B}$ activation could be blocked. As described in a previous study, IкB expression was driven by the cyto-megalo virus CMV promoter from the plasmid pCMV-IкB $\alpha$ (also known as pCMV-RLIF) (30). On d 3, the cells were stimulated with MDMA; the concentrations used were $1 \times 10^{-6}$ $M, 1 \times 10^{-5} \mathrm{M}, 1 \times 10^{-4} \mathrm{M}, 1 \times 10^{-3} \mathrm{M}$, and $1 \times 10^{-2} \mathrm{M}$. MDMA was dissolved in $2 \mathrm{~mL}$ of cell culture medium and gently added to each well in duplicates. Cell culture medium alone (without drug) was added to cells that served as our controls $(0 M)$. The cells were returned to the incubator for $24 \mathrm{~h}$. On d 4, the cells were lysed and the lysate was analyzed for firefly and Renilla luciferase activities using a dual-injector luminometer. A dual-luciferase method was used in order to control for possible differences in transfection efficiency and cell viability between independently treated culture wells. The ratio of experimental signal to internal control signal was determined.

\section{Intracellular Calcium and Mitochondrial Depolarization Measurements}

Several classes of pharmacological agents were utilized alone or in combination to determine changes in cytosolic calcium. To assess changes in intracellular and mitochondrial calcium, we used rhod- 2 and fluo-3. The mitochondrial potentiometric indicator JC-1 was used to determine mitochondrial depolarization. Fluorescent indicators fluo-3 AM, rhod-2 AM, and JC-1 were obtained from Molecular Probes (Eugene, OR) and dissolved in dry dimethyl sulfoxide (DMSO) at stock solutions that permitted a 1:1000 dilution to achieve the final loading concentrations of $5 \mu M, 5 \mu M$, and $2 \mu \mathrm{g} / \mathrm{mL}$, respectively. For some experiments, rhod-2 AM in DMSO was reduced with sodium borohydride to permit a more specific loading of the reduced indicator into mitochondria (31). Loading buffer comprised Hank's Modified Eagle's Medium without FBS or phenol red, but with $0.01 \%$ pluronic 127 for the calcium and ROS indicators. The pluronic 127 was added before the addition of the indicator(s). The loading medium was then sonicated for 2 min before the cells were washed and loading medium added. The cells were incubated in the presence of the indicators for $30-60 \mathrm{~min}$ at $37^{\circ} \mathrm{C}$ in $95 \%$ air $/ 5 \% \mathrm{CO}_{2}$. Cells were then washed to remove excess indicator and then maintained at $25^{\circ} \mathrm{C}$ for the remainder of the experiment.

Measurements were taken in the multiwell plates using a custom holder in a Zeiss 510 laser confocal microscope with Meta attachments (Zeiss, Jena, Germany). All measurements were made using a Zeiss 10X Plan Neofluar objective. The frame size was $512 \times 512$ pixels with 1024 -byte resolution. Nominal optical section thickness was $2 \mu \mathrm{m}$ with voxel size equal to $6.5 \mu \mathrm{m}^{3}$ and approx 15-30 optical sections were obtained. The emission filters were a Zeiss 560 LP (long pass) used for rhod-2 and a Zeiss BP (band pass) 505-550 for fluo-3. The primary dichroic was a Zeiss HFT 488/543 to separate the 488 and 543 laser lines and reflect the 543 wavelength to a Zeiss NFT 545 dichroic placed in front of the LP560 filter. The pinhole sizes used were set to a nominal 1.0 Airy units, which for the $\times 10$ objective was 80 and $76 \mu \mathrm{m}$ for the red and green channels, respectively. Laser settings were adjusted to achieve minimal photobleaching or photo-activation. Control measurements indicated no significant increase or decrease of indicator intensity during the entire protocol. Background subtraction was taken from indicator loaded/nonstimulated cells, while a saturated signal for internal normalization was obtained by introducing the calcium ionophore ionomycin.

The generic protocol included obtaining a control measurement, removing Hank's buffer with selected pretreatment agents, and then adding buffer with or without cocaine hydrochloride (Sigma, St. Louis, MO) at $10^{-5}$ to $10^{-2} \mathrm{M}$ along with any pretreatment agents. Measurements were made at 2 and 5 min postaddition, followed by 2- and 5-min measurements after the addition of 10-50 $\mu \mathrm{M}$ ionomycin or A23187 (Sigma) to elevate intracellular calcium activity or 
$50 \mu M$ carbonyl cyanide m-chlorophenyl hydrazone (CCCP; Sigma) to uncouple mitochondria during JC1 experiments. $\mathrm{K}_{\mathrm{d}} \mathrm{s}$ of 390 and $570 \mathrm{n} M$ (determined at $22^{\circ} \mathrm{C}$ in $0.1 \mathrm{M} \mathrm{KCl}, \mathrm{pH} 7.1$, by manufacturer) were used to estimate intracellular calcium activities for fluo-3 and rhod-2, respectively. To permit comparison of mitochondrial membrane depolarization, we calculated the ratio of the red (polarized $=\mathrm{P}$ )/green $($ depolarized $=\mathrm{D})$ JC-1 signals, correcting for their respective background fluorescence. Thus Ratio $=(\mathrm{P}-$ red background/D-green background). The change in mitochondrial fluorescence was expressed as percent change from the difference of the untreated, control cell ratio and the CCCP treated, depolarized cell ratio for that well. Three separate wells for each experimental manipulation were analyzed on different days for each experimental condition.

\section{Analysis of Gene Expression by Macarray and RT-PCR}

H9c2 cells in six flasks, each approx $85 \%$ confluent, were equally and randomly divided into two groups: $0 M$ MDMA (no MDMA in medium) and $1 \times 10^{-3} M$ MDMA dissolved in medium. The cell medium was removed and discarded. Ten milliliters of the drug solution was made fresh and added to each flask according to its treatment group: $0 M$ MDMA (medium only), or $1 \times 10^{-3} M$ MDMA in medium. After $24 \mathrm{~h}$ of stimulation, the drug solution was removed and discarded. Adherent cells were loosened by exposing the cell monolayer to $2 \mathrm{~mL}$ of $0.25 \%$ trypsin EDTA. After 2 min trypsin was removed and discarded. The cells were then resuspended in $10 \mathrm{~mL}$ of fresh medium and centrifuged at $5000 \mathrm{~g}$ for $10 \mathrm{~min}$ at $4^{\circ} \mathrm{C}$. The supernatant was removed and discarded. Cell pellets were gently washed with $1 \mathrm{~mL}$ phosphate buffered saline (PBS) and centrifuged in a new RNase-free mini-centrifuge tube at $12,000 \mathrm{~g}$ for $4 \mathrm{~min}$ at room temperature. The PBS was removed and discarded.

The Trizol method was used to extract total RNA (GibcoBRL, Grand Island, NY). Trizol ( $0.3 \mathrm{~mL}$ ) was added to each tube and the contents were mixed by inversion for $2 \mathrm{~min}$. Chloroform $(0.1 \mathrm{~mL})$ was added to each tube and the contents mixed by shaking for $15 \mathrm{~s}$. All tubes were incubated for $2 \mathrm{~min}$ at room temperature. The tubes were then centrifuged at $12,000 \mathrm{~g}$ for $10 \mathrm{~min}$. The supernatant (containing RNA) was carefully removed and placed into new RNase-free mini-centrifuge tubes. An equal volume of $100 \%$ isopropanol was added to precipitate the RNA. After centrifugation at $12,000 \mathrm{~g}$ for $10 \mathrm{~min}$, the supernatant was removed and discarded. The RNA pellet was resuspended in 70\% ethanol (made in diethyl pyrocarbonate [DEPC] water) and centrifuged again at $12,000 \mathrm{~g}$ for $5 \mathrm{~min}$, after which the supernatant was removed and discarded. The RNA pellet was air dried and then reconstituted with DEPC water.

cDNA was made from total RNA using a probe synthesis kit obtained from SuperArray. After prehybridization with denatured sheared salmon sperm DNA $(100 \mu \mathrm{g} / \mathrm{mL})$, the probe was added to the hybridization tubes and incubated for $48 \mathrm{~h}$ at $60^{\circ} \mathrm{C}$ with continuous agitation at $7280 \mathrm{~g}$. For chemiluminescent detection, the membrane was washed, blocked, and then incubated with alkaline phosphatase-conjugated streptavidin (1:7,500 dilution) for $10 \mathrm{~min}$ at room temperature with gentle agitation. The membranes were exposed to substrate and then placed into sealed plastic bags for imaging. The membranes were photographed using a VersaDoc digital imaging system (Bio-Rad, Hercules, CA) with a computer program interface to quantify chemiluminescent signals for each spot on the array (Quantity One). GEArray ${ }^{\mathrm{TM}} \mathrm{Q}$ Series Kits from SuperArray (Frederick, $\mathrm{MD})$ were used to assess gene activation or repression. One array contained genes important to cardiovascular pathology (Mouse Cardiovascular Disease I: Biomarkers). The other array contained genes important to cardiovascular toxicology (Mouse Stress \& Toxicity Pathway Finder). Each membrane for a given macroarray contained 96 genes.

To verify the results obtained from the macroarray experiments, we performed gene-specific RT-PCR utilizing kits obtained from SuperArray. cDNA was made from the total RNA isolated in the array experiment. A temperature-gradient PCR was conducted with annealing temperatures ranging from $50^{\circ} \mathrm{C}$ to $65^{\circ} \mathrm{C}$. The PCR products were subjected to electrophoresis on 2\% agarose containing GelStar (Cambrex Bio Science, Rockland, ME). The gels were imaged under a UV illuminator and analyzed by densitometry. Because of the number of genes contained in the macroarray, we necessarily had to restrict confirmation to a few candidates. Change in expression levels seen with troponin I,VCAM-1, and proliferating cell nuclear antigen (PCNA) were confirmed by RT-PCR. 


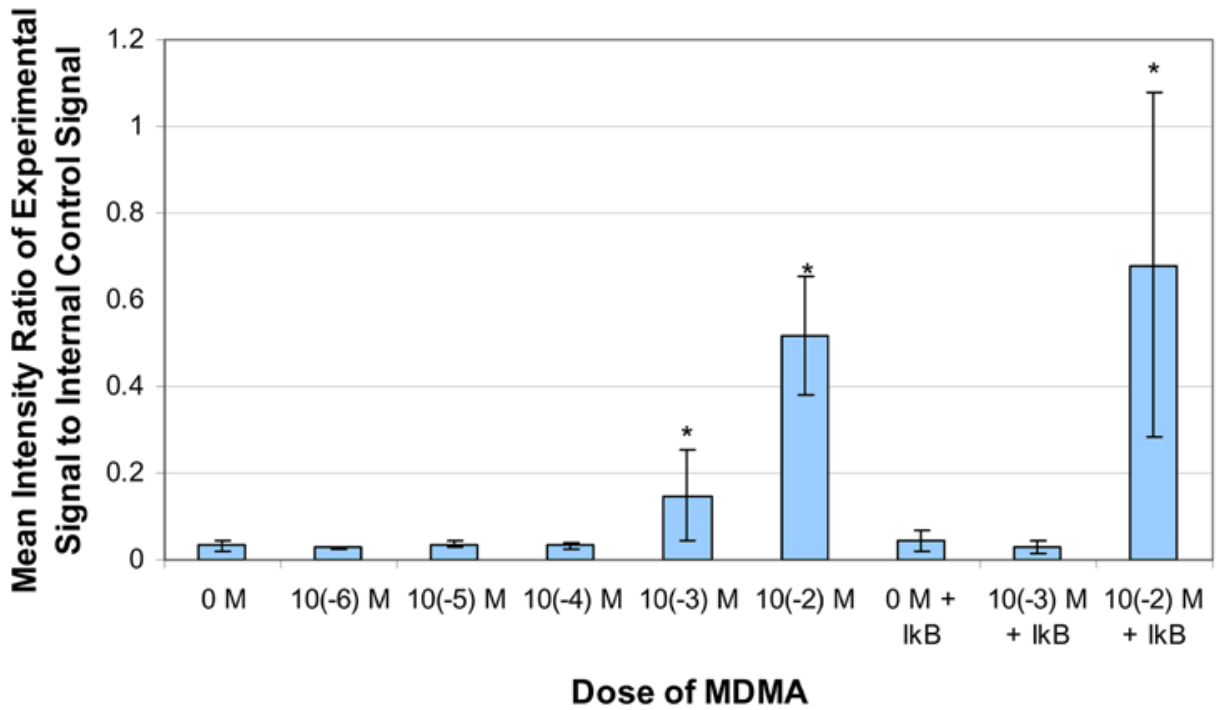

Fig. 1. Nuclear factor-kB reporter activity in H9c2 cells exposed to 3,4-methylenedioxymethamphetamine (MDMA; $n=3$ ) for $24 \mathrm{~h}$. Cells in wells that were not exposed to MDMA (0 M drug) received medium only and served as controls. Experiments involving IkB were performed independently. Data are expressed as a ratio (experimental signal/internal control signal) of mean relative luminometry units (RLU) $\pm \mathrm{SD}(* p>0.05)$.

\section{Data Analysis}

For luciferase activity, duplicate wells were averaged for three separate studies, and single-factor ANOVA followed by multiple comparison testing was performed on the mean values. For the gene expression array, raw signals were analyzed using GEArray Analyzer software available for download at the Super Array website (www.superarray.com). Background was subtracted from the blank on the membrane and normalized to the housekeeping gene for glyceraldehyde-3-phosphate dehydrogenase. According to SuperArray instructions, genes with a signal ratio $>2.0$ (experimental array/control array) and those with signal ratios $>1.0$ with raw intensities $>10 \%$ of the housekeeping gene were considered upregulated. Genes with a ratio $<0.5$ were considered downregulated. Activation of three genes was verified with RT-PCR. When assessing changes in intracellular calcium, we collected the average intensity measurements for 20 cells per field at each optical section, using areas of 60-100 pixels within the respective cell. Data files were collected in Metamorph, and then transferred to an Excel spreadsheet for subsequent statistical analysis by paired $t$-test. All data are stated as the mean \pm standard deviation unless otherwise indicated.

\section{Results}

\section{NF-кB Genetic Reporter Experiments}

These experiments were performed to determine the effect of MDMA on NF- $\mathrm{KB}$ activation in cultured cardiac myocytes. In cultured H9c2 cells, MDMA significantly activated NF- $\mathrm{KB}$ at concentrations of $1 \times 10^{-3} M$ and $1 \times 10^{-2} M$. However, the drug was unable to cause activation at the lower concentrations tested. This indicates that MDMA activates NF- $\kappa \mathrm{B}$ in cultured $\mathrm{H} 9 \mathrm{c} 2$ cells in a dose-dependent manner. Also, cotransfection of $I \kappa B$ significantly reduced NF- $\kappa$ B activity caused by $1 \times 10^{-3} M$ MDMA, but not by $1 \times 10^{-2} M$ MDMA (Fig. 1 ).

\section{Confocal Microscopy Experiments}

To determine if MDMA increased intracellular calcium levels and/or caused mitochondrial depolarization in $\mathrm{H} 9 \mathrm{c} 2$ cells, we performed quantitative confocal microscopy using standard fluorescent calcium indicators and the potentiometric JC-1 indicator, respectively. Figure 2 shows a significant increase in intracellular calcium 2 and 5 min after MDMA exposure. Figure 3A (cells stimulated with medium only and serving as controls) and $3 \mathrm{~B}$ (cells stimulated with $1 \times 10^{-2} M$ MDMA) show a representative ex- 


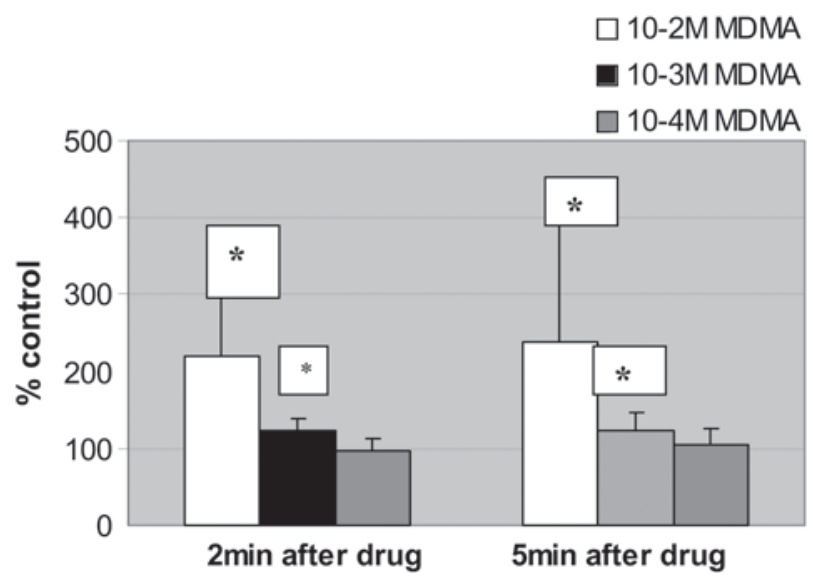

Fig. 2. Changes in intracellular calcium in $\mathrm{H} 9 \mathrm{c} 2$ cells 2 and $5 \mathrm{~min}$ after exposure to 3,4-methylenedioxymethamphetamine (MDMA). The cells were incubated in the presence of the indicator for $30-60 \mathrm{~min}$ at $37^{\circ} \mathrm{C}$ in $95 \%$ air $/ 5 \% \mathrm{CO}_{2}$ and then stimulated with MDMA. Data are stated as percent of control. * indicates $p<0.01$.
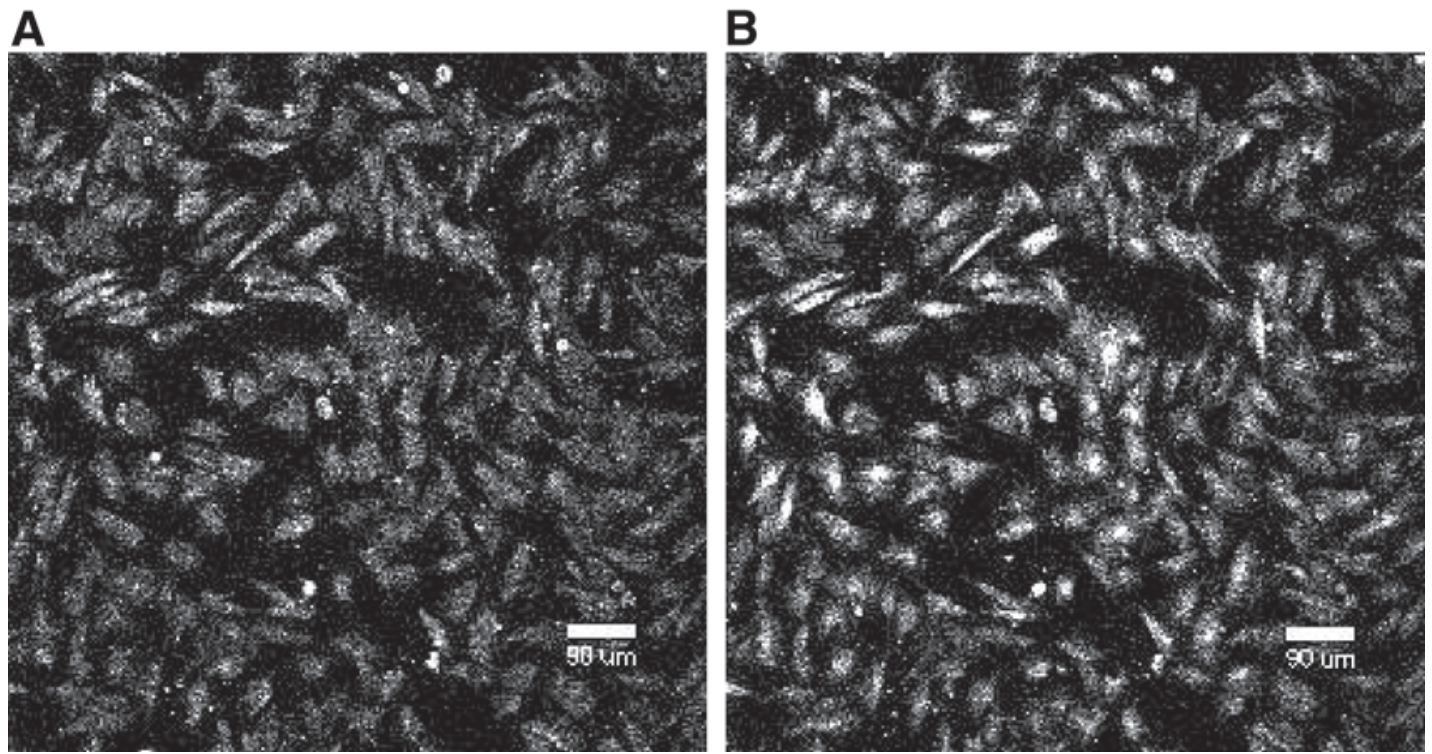

Fig. 3. (A) A representative example of $\mathrm{H} 9 \mathrm{c} 2$ cells loaded with the calcium indicator Fluo 3 and stimulated acutely with medium only (control). The cells were incubated in the presence of the indicator for $30-60 \mathrm{~min}$ at $37^{\circ} \mathrm{C}$ in $95 \%$ air $/ 5 \%$ $\mathrm{CO}_{2}$ and then stimulated with 3,4-methylenedioxymethamphetamine (MDMA). (B) A representative example of H9c2 cells loaded with the calcium indicator Fluo 3 and stimulated acutely with MDMA $1 \times 10^{-2} \mathrm{M}$. Each well served as its own control. The measure bar is $90 \mathrm{~mm}$.

ample of cells incubated with the fluorescent calcium indicator fluo-3 and stimulated acutely with and without MDMA. These results suggest that MDMA can increase intracellular calcium in a concentrationand time-dependent manner.

Figure $4 \mathrm{~A}$ (cells stimulated with medium only and serving as controls) and 4B (cells stimulated with MDMA $1 \times 10^{-2} M$ ) show a representative example of $\mathrm{H} 9 \mathrm{c} 2$ cells pretreated with the mitochondrial-speci- fic potentiometric indicator JC- 1 and stimulated with or without MDMA. MDMA caused depolarization of mitochondrial membranes, suggesting that this drug is detrimental to energy homeostasis in cardiac myocytes.

\section{Gene Analysis Experiments}

These experiments were performed after the luminometry experiments revealed the minimally effec- 

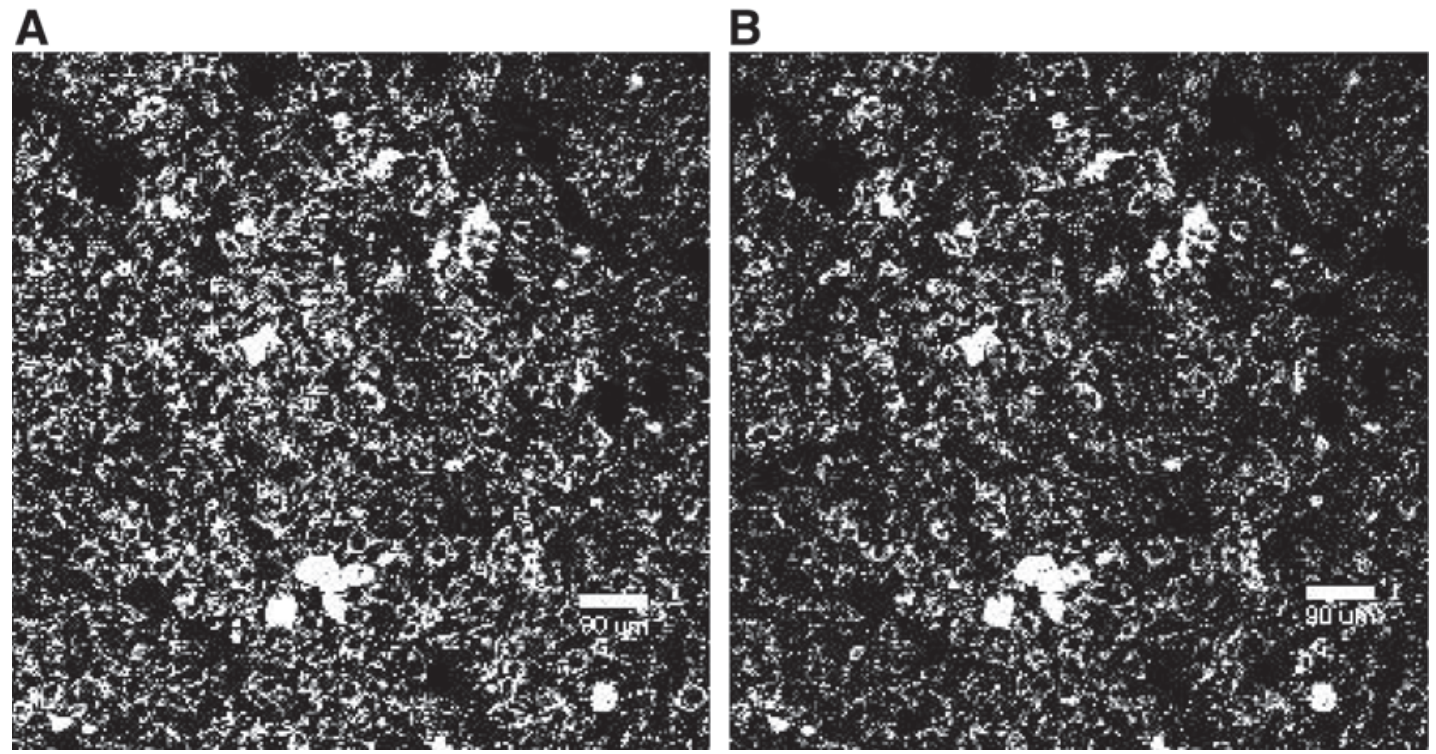

Fig. 4. (A) A representative example of $\mathrm{H} 9 \mathrm{c} 2$ cells loaded with the mitochondrial indicator JC-1 and stimulated acutely with medium only (control). The cells were incubated in the presence of the indicator for $30-60 \mathrm{~min}$ at $37^{\circ} \mathrm{C}$ in 95\% air/5\% $\mathrm{CO}_{2}$ and then stimulated with 3,4-methylenedioxymethamphetamine (MDMA). (B) A representative example of $\mathrm{H} 9 \mathrm{c} 2$ cells loaded with the mitochondrial indicator JC- 1 and stimulated acutely with MDMA $1 \times 10^{-2} M$. Each well served as its own control. The measure bar is $90 \mathrm{~mm}$.

tive concentration of MDMA required to cause NF$\kappa \mathrm{B}$ activation in cultured $\mathrm{H} 9 \mathrm{c} 2$ cells and to determine if MDMA activated the transcription of genes known to be associated with cardiovascular disease and stress toxicology. Exposure of H9c2 cells to $1 \times$ $10^{-3} \mathrm{M}$ MDMA for $24 \mathrm{~h}$ activated multiple genes that are considered to be biomarkers for cardiovascular disease and genes that are activated in response to toxicity and stress. The genes activated by a factor $\geq 2.0$ or $\leq 0.5$ are reported in Table 1 . Note that these values are derived from a single experimental determination and heterologous hybridization (rat on mouse). Activation of the troponin gene (Fig. 5), VCAM-1, and PCNA genes (Table 2) were verified with RT-PCR.

\section{Discussion}

MDMA is an extremely popular illicit drug with chronic abuse potential. The direct effects of MDMA on cardiac myocytes have not been fully characterized. In this study, we observed that MDMA $\left(1 \times 10^{-3} \mathrm{M}\right.$ and $\left.1 \times 10^{-2} M\right)$ significantly activates transcription factor NF- $\kappa$ B in cultured $\mathrm{H} 9 \mathrm{c} 2$ cells in a dose-dependent manner. Previous investigators have associated the abuse of MDMA with increased lymphocyte infiltration and inflammatory damage to the myocardium (3). Our current findings support a possible mechanism for this to occur. MDMA exposure activates NF- $\mathrm{BB}$, which in turn upregulates the expression of cytokines and cellular adhesion molecules that are important to the myocardial inflammatory response. This concept is supported by the fact that we observed the upregulation of genes associated with inflammation (Table 1A).

MDMA increased the transcription of the Cox-2 gene. This gene encodes for an enzyme known to be localized within regions of myocardial inflammation and fibrotic scar formation, especially in patients with congestive heart failure (32). The upregulation of the Scya2 and MIP-1b genes (Table 1A,B) suggests that these chemotactic proteins may promote leukocyte migration to the myocardium. The adhesion molecule gene VCAM-1 was strongly upregulated, displaying a notable 12-fold increase over control, the upregulation of which was verified by RT-PCR. VCAM-1 may be involved with leukocyte binding to the myocardium. This particular gene is specifically regulated by $\mathrm{NF}-\kappa \mathrm{B}$, corroborating the increased activity of NF- $\kappa$ B observed in our genetic reporter studies. 


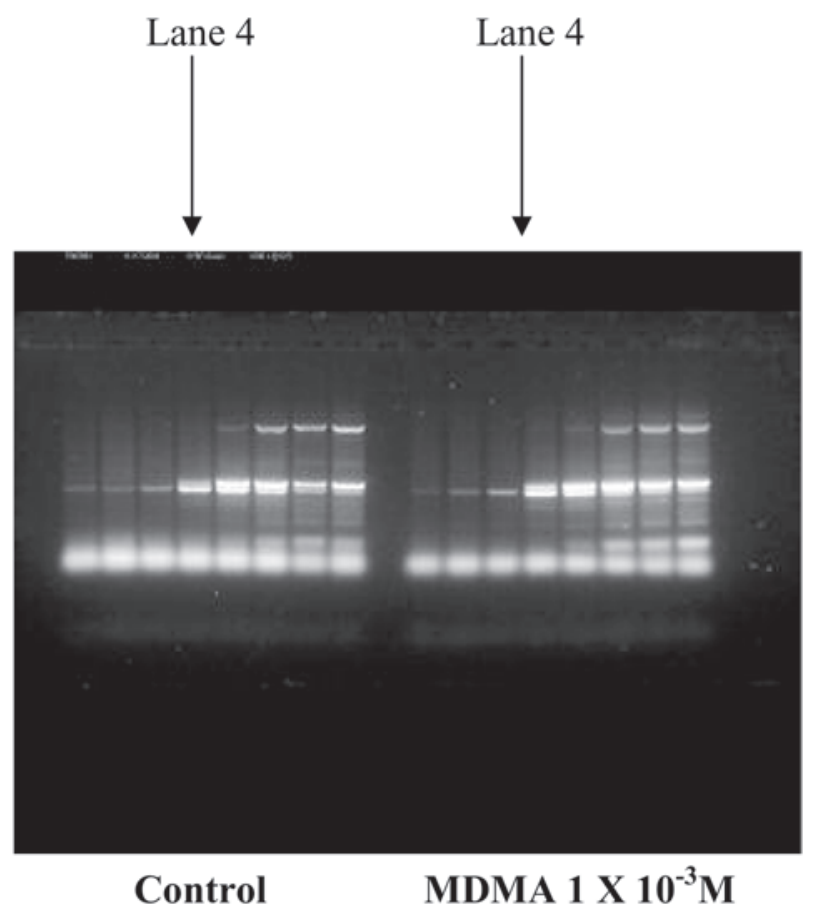

Fig. 5. A representative example of an agarose gel using temperature-gradient $\mathrm{PCR}$ conducted with annealing temperatures ranging from $50^{\circ} \mathrm{C}$ to $65^{\circ} \mathrm{C}$. The PCR product troponin 1 was subjected to electrophoresis on $2 \%$ agarose containing GelStar. The gel was imaged under a UV illuminator and analyzed by densitometry. The arrow indicates an annealing temperature of $59^{\circ} \mathrm{C}$ for $\mathrm{H} 9 \mathrm{c} 2$ cells stimulated with medium only (control) and $\mathrm{H} 9 \mathrm{c} 2$ cells treated with 3,4-methylenedioxymethamphetamine $1 \times 10^{-3} \mathrm{M}$.

The activity of two genes associated with myocardial remodeling and hypertrophy was also affected by MDMA. Gelatinase A, which encodes for a matrix-degrading enzyme, and its inhibitor (Timp) were downregulated. This suggests that MDMA may not alter the extracellular matrix. However, the increased transcription of growth-promoting genes such as cyclin D1, cyclin G, and PCNA suggests that MDMA may be prohypertrophic. The ability of MDMA to activate growth-related genes may act in synergy with its systemic ability to enhance the release of norepinephrine, a stimulator of hypertrophic growth in the chronically affected myocardium.

Several other key genes were activated in the presence of MDMA including heat shock proteins $\alpha B$ crystallin (cryab), mortalin-2 (PBP-74), HSP25, HSP 60 , and HSP4. These prosurvival genes are normally induced by chemical, hyperosmotic, and ischemic
Table 1

Genetic Array Summary

\begin{tabular}{lr}
\hline Gene & Ratio \\
\hline A. Cardiovascular array (CVD) & \\
Apoc2 & 7.12 \\
Scya2 & 8.47 \\
Gelatinase A & 0.05 \\
PLAUR & 7.70 \\
Timp & 0.41 \\
Troponin 1 & 6.12 \\
VCAM-1 & 12.13
\end{tabular}

B. Stress/toxicity array

caspase-1 0.41

caspase- $8 \quad 0.13$

cyclin D1 3.25

cyclin G 6.77

cryab (a-Crystallin B) $\quad 2.07$

Gadd45 2.41

hsp25 (hspb1) $\quad 3.55$

Hsp60 2.87

Hspa4 4.27

PBP74 2.43

PCNA $\quad 8.89$

Cox-2 4.29

RAD23A $\quad 5.27$

MIP-1b (Scya4) 2.13

FasL 0.23

p53 0.33

(A) Genes in the cardiovascular disease macroarray activated/ repressed by 3,4-methylenedioxymethamphetamine (MDMA): apolipoprotein-2 (Apoc2), chemokine ligand 2 (Scya2), plasminogen activator urokinase receptor (PLAUR), tissue inhibitor of metalloproteases (Timp), troponin 1, vascular cell adhesion molecule 1 (VCAM-1). (B) Genes in the stress/toxicity macroarray activated/repressed by MDMA: crystallin, a B (cryab), growth arrest and DNA damage inducible protein 45 (Gadd45), heat shock protein 60 (Hsp60), heart shock protein 4 (Hspa4), peptide binding protein 74 (PBP74), proliferating cell nuclear antigen (PCNA), cyclooxygenase-2 (Cox 2), chemokine ligand 4 (MIP-1b), fas ligand (FasL), tumor protein p53 (p53). The gene is listed as activated if the ratio of treated to control was 2.0 or greater or if the raw number indicating activity of the treated cells was $10 \%$ of the housekeeping gene $(\mathrm{GAPDH}=1.00)$. The gene is listed as repressed if the ratio of treated to control was 0.5 or less. Ratios are expressed as relative densitometry values (experimental/control).

insults. In addition, the upregulation of DNA-repair factors Gadd45 and RAD23A suggests that MDMA may also have genotoxic properties. The activation of these genes by MDMA suggests that the cells are 
Table 2

RT-PCR Summary of Gene Activity

\begin{tabular}{|c|c|c|c|}
\hline Gene & Treatment & $\begin{array}{c}\text { Net intensity } \\
\text { (arbitrary units) }\end{array}$ & $\begin{array}{l}\text { Annealing } \\
\text { temperature }\end{array}$ \\
\hline \multirow[t]{2}{*}{ Troponnin 1} & $\begin{array}{l}0 \text { M MDMA } \\
\text { (medium only: control) }\end{array}$ & 0.707 & $59.1^{\circ} \mathrm{C}$ \\
\hline & $10^{-3} M$ MDMA & 0.765 & \\
\hline \multirow{3}{*}{$\begin{array}{l}\text { Vascular cell adhesion } \\
\text { molecule } 1 \text { (VCAM-1) }\end{array}$} & $0 M$ MDMA & & \\
\hline & (medium only: control) & 0.430 & $59.1^{\circ} \mathrm{C}$ \\
\hline & $10^{-3} M$ MDMA & 0.879 & \\
\hline \multirow[t]{2}{*}{$\begin{array}{l}\text { Poly (A) polymerase } \\
\text { (PCNA) }\end{array}$} & $\begin{array}{l}0 M \text { MDMA } \\
\text { (medium only: control) }\end{array}$ & 0.452 & $63.8^{\circ} \mathrm{C}$ \\
\hline & $10^{-3} M$ MDMA & 0.491 & \\
\hline
\end{tabular}

Net intensity normalized to the housekeeping gene GAPDH of all genes was verified with RT-PCR. MDMA, 3,4-methylenedioxymethamphetamine.

stressed in some manner by the drug and that a cellular compensatory response is initiated to counteract exposure and promote survival. Furthermore, MDMA appeared to repress the proapoptotic genes caspase-1, caspase-8, and FasL, suggesting that under our experimental conditions, the adverse effects associated with MDMA may not be caused by activation of the apoptotic mechanism.

Genetic arrays provide the advantage of observing the activity of several genes simultaneously at the level of transcription. An obvious limitation is that posttranscriptional events may also influence the ultimate expression of a gene in question and this cannot be determined with the present methodology. Nevertheless, alterations in gene transcription are compelling first evidence that MDMA affects the cardiovascular system at the cellular level.

MDMA caused a significant increase in concentration of intracellular calcium in the H9c2 cells and this may have important implications for the intact heart. Disruptions in calcium homeostasis may abnormally alter myocardial excitability and contractility and induce arrhythmia or ventricular fibrillation. Increased intracellular calcium may also affect signaling pathways, leading to diverse responses including fibrosis and hypertrophy. In addition, calcium overload is also known to induce apoptosis via calcineurin-mediated dephosphorylation of $\mathrm{Bcl} 2$-antagonist of cell death (BAD) and subsequent migration of $\mathrm{BAD}$ to the mitochondria, where it initiates caspase activation (33). Whereas our findings did not show activation of caspase- 1 and caspase- 8 transcription, we did see mitochondrial depolarization in response to MDMA. Therefore, the net effect of MDMA-induced calcium overload on cardiac myocytes may be promotion of hypertrophic growth and mitochondrial damage.

In conclusion, this study provides evidence in support of the hypothesis that MDMA exposure, at certain concentrations, may be toxic to the myocardium. Acute intracellular calcium overload constitutes an immediate/early consequence of abusing this drug, which may contribute to cardiac rhythmic abnormalities. NF- $\kappa \mathrm{B}$ activation and perturbations in gene expression may lead to chronic sequelae, as it is likely that this compound may prove to be increasingly detrimental to the heart in long-term abusers.

\section{Acknowledgments}

This work was supported by a grant to Dr. Hargrave from the Jeffress Trust and by EVMS Institutional Incentive Funds from Dr. Lattanzio.

\section{References}

1. Kalant, H. (2001). The pharmacology and toxicology of "ecstasy" (MDMA) and related drugs. CMAJ 165:917-928.

2. Lester, S.J., Baggott, M., Welm, S., Schiller, N.B., Jones, R.T., Foster, E., et al. (2000). Cardiovascular effects of 3,4-methylenediosymethamphetamine. A double-blind, placebo-controlled trial. Ann. Intern. Med. 133:969-973.

3. Badon, L.A., Hicks, A., Lord, K., Ogden, B.A., MelegSmith, S., and Varner, K.J. (2002). Changes in cardiovascular responsiveness and cardiotoxicity elicited during binge administration of ecstasy. J. Pharmacol. Exp. Ther. 302:898-907. 
4. Brody, S., Krause, C., Veit, R., and Rau, H. (1998). Cardiovascular autonomic dysregulation in users of MDMA (“ecstasy"). Psychopharmacology 136:390-393.

5. Vandeputte, C. and Docherty, J.R. (2002). Vascular actions of 3,4-methylenedioxymethamphetamine in alpha(2A/D)adrenoceptor knockout mice. Eur. J. Pharmacol. 457:45-49.

6. Muth, J.N., Bodi, I., Lewis, W., Varadi, G., and Schwartz, A. (2001). A Ca(2+)-dependent transgenic model of cardiac hypertrophy: a role for protein kinase Calpha. Circulation 103:140-147.

7. Sen, R. and Baltimore, D. (1986). Multiple nuclear factors interact with the immunoglobulin enhancer sequences. Cell 46:705-716.

8. Kaltschmidt, C., Kaltschmidt, B., Neumann, H., Wekerle, H., and Baeuerle, P.A. (1994). Constitutive NF-kappa B activity in neurons. Mol. Cell. Biol. 14:3981-3992.

9. Lawrence, R., Chang, L.J., Siebenlist, U., Bressler, P., and Sonenshein, G.E. (1994). Vascular smooth muscle cells express a constitutive NF-kappa B-like activity. J. Biol. Chem. 269:28913-28918.

10. Grimm, S. and Baeuerle, P.A. (1993). The inducible transcription factor NF- $\kappa$ : structure-function relationship of its protein subunits. Biochem. J. 290:297-308.

11. Baeuerle, P.A. and Baltimore, D. (1988). I kappa B: a specific inhibitor of the NF-kappa B transcription factor. Science 242:540-546.

12. Baeuerle, P.A. and Baltimore, D. (1988). Activation of DNA-binding activity in an apparently cytoplasmic precursor of the NF- $\kappa \mathrm{B}$ transcription factor. Cell 53:211-217.

13. Henkel, T., Machleidt, T., Alkalay, I., Kronke, M., BenNeriah, Y., and Baeuerle, P.A. (1993). Rapid proteolysis of I kappa B-alpha is necessary for activation of transcription factor NF-kappa B. Nature 365:182-185.

14. Palombella, V.J., Rando, O.J., Goldberg, A.L., and Maniatis, T. (1994). The ubiquitin-proteasome pathway is required for processing the NF-kappa B1 precursor protein and the activation of NF-kappa B. Cell 78:773-785.

15. Traenckner, E.B., Pahl, H.L., Henkel, T., Schmidt, K.N., Wilk, S., and Baeuerle, P.A. (1995). Phosphorylation of human I kappa B-alpha on serines 32 and 36 controls I kappa B-alpha proteolysis and NF-kappa B activation in response to diverse stimuli. EMBO J. 14:2876-2883.

16. Thompson, J.E., Phillips, R.J., Erdjument-Bromage, H., Tempst, P., and Ghosh, S. (1995). I kappa B-beta regulates the persistent response in a biphasic activation of NF-kappa B. Cell 80:573-582.

17. Grilli, M., Chiu, J.J., and Lenardo, M.J. (1993). NF-kappa $\mathrm{B}$ and Rel: participants in a multiform transcriptional regulatory system. Int. Rev. Cytol. 143:1-62.

18. Siebenlist, U., Franzoso, G., and Brown, K. (1994). Structure, regulation and function of NF-kappa B. Annu. Rev. Cell Biol. 10:405-455.

19. Baeuerle, P.A. and Baltimore, D. (1996). NF-kappa B: ten years after. Cell 87:13-20.

20. Landry, D.B., Couper, L.L., Bryant, S.R., and Lindner, V. (1997). Activation of the NF-kappa B and I kappa B sys- tem in smooth muscle cells after rat arterial injury. Induction of vascular cell adhesion molecule-1 and monocyte chemoattractant protein-1. Am. J. Pathol. 151:1085-1095.

21. Brach, M.A., Hass, R., Sherman, M.L., Gunji, H., Weichselbaum, R., and Kufe, D. (1991). Ionizing radiation induces expression and binding activity of the nuclear factor kappa B. J. Clin. Invest. 88:691-695.

22. Schreck, R., Rieber, P., and Baeuerle, P.A. (1991). Reactive oxygen intermediates as apparently widely used messengers in the activation of the NF-kappa B transcription factor and HIV-1. EMBO J. 10:2247-2258.

23. Peng, M., Huang, L., Xie, Z.J., Huang, W.H., and Askari, A. (1995). Oxidant-induced activations of nuclear factorkappa B and activator protein-1 in cardiac myocytes. Cell Mol. Biol. Res. 41:189-197.

24. Hattori, Y., Akimoto, K., Murakami, Y., and Kasai, K. (1997). Pyrrolidine dithiocarbamate inhibits cytokine-induced VCAM-1 gene expression in rat cardiac myocytes. Mol. Cell. Biochem. 177:177-181.

25. Kacimi, R., Karliner, J.S., Koudssi, F., and Long, C.S. (1998). Expression and regulation of adhesion molecules in cardiac cells by cytokines: response to acute hypoxia. Circ. Res. 82:576-586.

26. Mustapha, S., Kirshner, A., De Moissac, D., and Kirshenbaum, L.A. (2000). A direct requirement of nuclear factorkappa B for suppression of apoptosis in ventricular myocytes. Am. J. Physiol. Heart Circ. Physiol. 279:H939-H945.

27. Montiel-Duarte, C., Ansorena, E., Lopez-Zabalza, M.J., Cenarruzabeitia, E., and Iraburu, M.J. (2004). Role of reactive oxygen species, glutathione and NF-kappaB in apoptosis induced by 3,4-methylenedioxymethamphetamine ("ecstasy") on hepatic stellate cells. Biochem. Pharmacol. 67:1025-1033.

28. Shankaran, M., Yamamoto, B.K., and Gudelsky, G.A. (1999). Involvement of the serotonin transporter in the formation of hydroxyl radicals induced by 3,4-methylenedioxymethamphetamine. Eur. J. Pharmacol. 385:103-110.

29. Hargrave, B.Y., Tiangco, D.A., Lattanzio, F.A., and Beebe, S.J. (2003). Cocaine, not morphine, causes the generation of reactive oxygen species and activation of NF-kappaB in transiently cotransfected heart cells. Cardiovasc. Toxicol. 3:141-151.

30. Regnier, C.H, Spong, H.Y, Gao, X, Goeddel, D.V., Cao, $\mathrm{Z}$, and Rothe, M. (1997). Identification and characterization of an IkappaB kinase. Cell 90: 373-383.

31. Williams, D.A., Bowser, D.N., and Petrou, S. (1999). Confocal $\mathrm{Ca}^{2+}$ imaging of organelles, cells, tissues, and organs. Methods Enzymol. 307:441-469.

32. Wong, S.C., Fukuchi, M., Melnyk, P., Rodger, I., and Giaid, A. (1998). Induction of cyclooxygenase-2 and activation of nuclear factor-kappaB in myocardium of patients with congestive heart failure. Circulation 98:100-103.

33. Wang, H.G., Pathan, N., Ethell, I.M., Krajewski, S., Yamaguchi, Y., Shibasaki, F., et al. (1999). Ca ${ }^{2+}$-induced apoptosis through calcineurin dephosphorylation of BAD. Science 284:339-343. 